Louisiana State University

LSU Digital Commons

$8-1-2006$

\title{
Thermalkalibacillus uzonensis gen. nov. sp. nov, a novel aerobic alkali-tolerant thermophilic bacterium isolated from a hot spring in Uzon Caldera, Kamchatka
}

\author{
Weidong Zhao \\ University of Georgia \\ Carolyn Weber \\ University of Maine \\ Chuanlun L. Zhang \\ University of Georgia \\ Christopher S. Romanek \\ Savannah River Ecology Laboratory \\ Gary M. King \\ University of Maine
}

See next page for additional authors

Follow this and additional works at: https://digitalcommons.Isu.edu/biosci_pubs

\section{Recommended Citation}

Zhao, W., Weber, C., Zhang, C., Romanek, C., King, G., Mills, G., Sokolova, T., \& Wiegel, J. (2006).

Thermalkalibacillus uzonensis gen. nov. sp. nov, a novel aerobic alkali-tolerant thermophilic bacterium isolated from a hot spring in Uzon Caldera, Kamchatka. Extremophiles, 10 (4), 337-345. https://doi.org/ 10.1007/s00792-006-0511-6

This Article is brought to you for free and open access by the Department of Biological Sciences at LSU Digital Commons. It has been accepted for inclusion in Faculty Publications by an authorized administrator of LSU Digital Commons. For more information, please contact ir@lsu.edu. 
Authors

Weidong Zhao, Carolyn Weber, Chuanlun L. Zhang, Christopher S. Romanek, Gary M. King, Gary Mills, Tatyana Sokolova, and Juergen Wiegel 
ORIGINAL PAPER

Weidong Zhao · Carolyn Weber · Chuanlun L. Zhang

Christopher S. Romanek · Gary M. King

Gary Mills · Tatyana Sokolova $\cdot$ Juergen Wiegel

\section{Thermalkalibacillus uzonensis gen. nov. sp. nov, a novel aerobic alkali-tolerant thermophilic bacterium isolated from a hot spring in Uzon Caldera, Kamchatka}

Received: 4 November 2005/ Accepted: 5 December 2005/Published online: 25 March 2006

(C) Springer-Verlag 2006

\begin{abstract}
A novel thermophilic, alkali-tolerant, and COtolerant strain $\mathrm{JW} / \mathrm{WZ}-\mathrm{YB} 8^{\mathrm{T}}$ was isolated from green mat samples obtained from the Zarvarzin II hot spring in the Uzon Caldera, Kamchatka (Far East Russia). Cells were Gram-type and Gram stain-positive, strictly aerobic, $0.7-0.8 \mu \mathrm{m}$ in width and $5.5-12 \mu \mathrm{m}$ in length and produced terminal spherical spores of $1.2-1.6 \mu \mathrm{m}$ in diameter with the mother cell swelling around $2 \mu \mathrm{m}$ in diameter (drumstick-type morphology). Cells grew optimally at $\mathrm{pH}^{25^{\circ} \mathrm{C}} 8.2-8.4$ and temperature $50-52^{\circ} \mathrm{C}$ and tolerated maximally $6 \%(\mathrm{w} / \mathrm{v}) \mathrm{NaCl}$. They were
\end{abstract}

Communicated by F. Robb

The Genbank accession number for the 16S rRNA gene sequence of strain JW/WZ-YB58 ${ }^{\mathrm{T}}$ is DQ221694.

W. Zhao $\cdot$ C. L. Zhang

Department of Marine Sciences, University of Georgia, Athens, GA 30602, USA

W. Zhao $\cdot$ C. L. Zhang $\cdot$ C. S. Romanek $\cdot$ G. Mills Savannah River Ecology Laboratory, University of Georgia, Aiken, SC 29802, USA

C. Weber $\cdot$ G. M. King

Darling Marine Center, University of Maine, Walpole, ME 04573, USA

C. S. Romanek

Department of Geology, University of Georgia, Athens, GA 30602, USA

T. Sokolova

Russian Academy of Sciences, Institute of Microbiology, 117312 Moscow, Russian Federation

J. Wiegel $(\bowtie)$

Departments of Microbiology and of Biochemistry \&

Mol. Biology, University of Georgia,

211-212C Biological Sciences Bldg.,

1000 Cedar Street, Athens, GA 30602-2605, USA

E-mail: jwiegel@uga.edu

Tel.: 1-706-5422651

Fax: + 1-706-5422674 strict heterotrophs and could not use either $\mathrm{CO}$ or $\mathrm{CO}_{2}$ (both with or without $\mathrm{H}_{2}$ ) as sole carbon source, but tolerated up to $90 \%(\mathrm{v} / \mathrm{v}) \mathrm{CO}$ in the headspace. The isolate grew on various complex substrates such as yeast extract, on carbohydrates, and organic acids, which included starch, D-galactose, D-mannose, glutamate, fumarate and acetate. Catalase reaction was negative. The membrane polar lipids were dominated by branched saturated fatty acids, which included iso-15:0 (24.5\%), anteiso-15:0 (18.3\%), iso-16:0 (9.9\%), iso-17:0 (17.5\%) and anteiso-17:0 (9.7\%) as major constituents. The DNA $\mathrm{G}+\mathrm{C}$ content of the strain is $45 \mathrm{~mol} \%$. Phylogenetic analyses based on 16S rRNA gene sequences revealed that strain $\mathrm{JW} / \mathrm{WZ}-\mathrm{YB} 58^{\mathrm{T}}$ is distantly $(<93 \%$ similarity) related to members of Bacillaceae. On the basis of 16S rRNA gene sequence, physiological and phenotypic characteristics, the isolate $\mathrm{JW} / \mathrm{WZ}-\mathrm{YB} 58^{\mathrm{T}}$ (ATCC BAA-1258; DSM 17740) is proposed to be the type strain for the type species of the new taxa within the family Bacillaceae, Thermalkalibacillus uzoniensis gen. nov. sp. nov. The Genbank accession number for the 16S rRNA gene sequence is DQ221694.

Keywords Bacillales Bacillaceae Thermophilic Alkaliphilic $\cdot$ Carbon monoxide-tolerant $\cdot$ Fatty acids · Firmicutes

\section{Introduction}

Alkali-tolerant bacteria and alkaliphiles have been investigated for decades for their potential in industrial application and biotechnology (Horikoshi 1999, 2004). Many of these organisms are mesophilic and halophilic (Nielsen et al. 1995; Horikoshi 2004). Thermophilic representatives, however, are less well known. Many previously described aerobic alkaliphiles and alkali-tolerant bacteria belong to the Firmicutes, and are represented by species within the Bacillaceae (Nielsen et al. 1995; Blum et al. 1998; Yumoto et al. 1998, 2003), al- 
though many thermophiles are not validly published taxa (Kevbrin et al. 2004).

The family Bacillaceae is presently one of the taxonomically and phylogenetically diverse taxa undergoing revaluation. Based on the $16 \mathrm{~S}$ rRNA gene sequences and $\mathrm{G}+\mathrm{C}$ contents, many members of Bacillaceae have been re-classed from the genus Bacillus to novel genera, or even to a novel family, for example, Alicyclobacillaceae (Garrity et al. 2004). Currently (January 2006), the family Bacillaceae contains 24 genera (http://www.ncbi.nlm. nih.gov/Taxonomy/Browser/wwwtax.cgi). Most bacteria within these genera share the features of being aerobic or microaerophilic, Gram-type and Gram stain-positive and spore-forming rods. However, diversity within Bacillaceae species may result in creation of more novel genera and more separation from the genus Bacillus.

During the course of enrichments for carboxydotrophic bacteria from $\mathrm{CO}$-oxidizing hot spring microbial mats in the Uzon Caldera, Kamchatka, we isolated a novel member of the Bacillaceae (strain JW/WZ-YB58) that tolerates high CO concentrations (up to $90 \%$ ), but appears unable to utilize $\mathrm{CO}$ as a carbon or energy source. CO tolerance has been reported previously for several members of the Proteobacteria (Cypionka and Meyer 1982), but has not been documented for Firmicutes. King (2003) has shown that some CO-oxidizing bacteria only consume $\mathrm{CO}$ at low $(<$ about $1 \%$ ) concentrations. To verify the potential for CO-utilization, King (2003) used a polymerase chain reaction (PCR) assay to amplify the large sub-unit gene $(\operatorname{cox} L)$ of $\mathrm{CO}$ dehydrogenase. Primers for this assay (King 2003) have been used to successfully amplify coxL from another member of the Bacillaceae, the carboxydotroph, Bacillus schlegelii (Dunfield and King 2004).

\section{Methods}

\section{Sampling and Enrichment}

Enrichments were carried out using a suspended mat sample obtained from the Zarvarzin II hot spring in the Uzon Caldera, Kamchatka, Russia, which previously oxidized $\mathrm{CO}$ when incubated with concentrations from 3 to $5 \%$ (Wiegel and Weber, unpublished data). The mat was greenish in color, located at the edges of the pool and frequently, totally submerged by the splashing pool water but intermittently exposed to air. Water temperature varied from 55 to $72^{\circ} \mathrm{C}$ at the sampling location; the temperature below the mat surface $(0.5-2 \mathrm{~cm}$ thick) was 55 to $65^{\circ} \mathrm{C}$. The $\mathrm{pH}$ of the spring varied from 6.0 to 7.5 within the mats and at the locations where mats were collected.

Mineral media supplemented with $0.05 \%(\mathrm{w} / \mathrm{w})$ yeast extract and 20-27 mM pyruvate were used for enrichment and subsequent isolations. The mineral media contained ( $\mathrm{L}^{-1}$ distilled water): $1 \mathrm{~g} \mathrm{NH}_{4} \mathrm{Cl}, 3.6 \mathrm{~g} \mathrm{NaCl}, 1 \mathrm{~g}$ $\mathrm{KCl}, 0.5 \mathrm{~g} \mathrm{Na}_{2} \mathrm{SO}_{4}, 0.04 \mathrm{~g} \mathrm{CaCl}, 0.04 \mathrm{~g} \mathrm{MgCl}_{2} \cdot 6 \mathrm{H}_{2} \mathrm{O}$, $0.5 \mathrm{~g} \mathrm{NaH}_{2} \mathrm{PO}_{4}$ and $1 \mathrm{~g} \mathrm{~K}_{2} \mathrm{HPO}_{4}, 1-\mathrm{mL}$ vitamin solution,
1-mL trace-element solution and $1-\mathrm{mL} \mathrm{Na}_{2} \mathrm{SeO}_{3-}$ $\mathrm{Na}_{2} \mathrm{WO}_{3}$ solution (Widdel and Bak 1992). The $\mathrm{pH}$ of the media was adjusted to 8.5 by titration with $2-\mathrm{M} \mathrm{NaOH}$. Serum bottles $(125-\mathrm{mL})$ for tenfold-dilution series contained $15-\mathrm{mL}$ media and $2-4 \%(\mathrm{v} / \mathrm{v}) \mathrm{CO}$ in air as the headspace. Cultures were incubated at $60^{\circ} \mathrm{C}$ for up to 4 weeks. Positive-growth cultures from the highest dilution were used as inocula for three successive transfers on agar $(2 \% \mathrm{w} / \mathrm{v})$ plates. Agar plates were incubated in anaerobic containers (Difco) having approximately $4 \%$ (v/v) of CO in the air headspace. Colonies from the third batch of plates were transferred to liquid media. Cells in the culture were checked for uniformity by phase-contrast light microscopy (Olympus VANOX) and later by 16S rRNA sequence analysis.

\section{Utilization of electron donors and acceptors}

The ability of the bacterium to utilize different substrates was studied in mineral media containing $0.02 \%(\mathrm{w} / \mathrm{v})$ yeast extract (Difco) supplemented with filter-sterilized substrate stock solutions (final substrate concentrations $20 \mathrm{mM}$ ). Autotrophic growth of the bacterium was checked using mineral media containing $0.02 \%(\mathrm{w} / \mathrm{v})$ yeast extract under a gas phase of $5 \%(\mathrm{v} / \mathrm{v}) \mathrm{CO}$ or $10 \%$ $\mathrm{CO}_{2}$ plus and minus $20 \% \mathrm{H}_{2}(\mathrm{v} / \mathrm{v})$ and balanced by air.

The $\mathrm{CO}$ utilization of enrichments and pure cultures was assessed by gas chromatography (Carle Analytical Gas Chromatograph Series 400 by Chandler Engineering LLC) equipped with a thermal conductivity detector, using helium as carrier gas, and an oven temperature of $70^{\circ} \mathrm{C}$. The CO-tolerant range for the isolate was determined in mineral media supplemented with $0.05 \%(\mathrm{w} / \mathrm{v})$ yeast extract, $30 \mathrm{mM}$ lactate and air as head gas containing 10 to $90 \%(\mathrm{v} / \mathrm{v})$ of $\mathrm{CO}$. To assess the oxidation of $\mathrm{CO}$ at low concentration $(100 \mathrm{ppm})$, the isolate was grown at $50^{\circ} \mathrm{C}$ in stoppered $60-\mathrm{ml}$ serum bottles containing $5 \mathrm{ml}$ of basal salts medium with $25 \mathrm{mM}$ pyruvate and $0.05 \%$ yeast extract. CO was added to the headspace at a final concentration of $100 \mathrm{ppm}$. Using a needle and syringe headspace samples were obtained at intervals over a $57-\mathrm{h}$ period. Samples were assayed using a Trace Analytical reduced gas detector (model RGA3) (Hardy and King 2001).

The use of electron acceptors was determined in anaerobic nutrient-broth media under $\mathrm{N}_{2}$ atmosphere and supplemented with autoclaved stock solutions of $15 \mathrm{mM}$ electron acceptors, that is, fumarate, nitrate, nitrite, sulfate, thiosulfate, $\mathrm{Fe}(\mathrm{III})$ hydroxide and Fe(III) citrate. Freshly grown aerobic cultures to be used as inoculum were pre-flushed with oxygen-free $\mathrm{N}_{2}$ gas and supplemented with $\mathrm{Na}_{2} \mathrm{~S} \cdot 9 \mathrm{H}_{2} \mathrm{O}\left(0.5 \mathrm{~g} \mathrm{~L}^{-1}\right)$ to remove trace amounts of oxygen. The cultures were incubated for up to 2 weeks at $52^{\circ} \mathrm{C}$. Utilization of a particular substrate or an electron acceptor by the culture was determined by both direct cell counts using a phasecontrast microscope and by measuring the increase in optical density at $600 \mathrm{~nm}$. Controls containing mineral 
medium with $0.02 \%(\mathrm{w} / \mathrm{v})$ yeast extract were performed in triplicate. Positive growth of a culture was based on an optimal density at $600 \mathrm{~nm}$ (Spectronic 21; Baush \& Lomb) that was at least two times higher than that of the controls.

Temperature, $\mathrm{pH}$ and $\mathrm{NaCl}$ concentration

The ranges and optima of temperature, $\mathrm{pH}$ and $\mathrm{NaCl}$ concentration for growth were determined using mineral media supplemented with $0.05 \%(\mathrm{w} / \mathrm{v})$ yeast extract and $20 \mathrm{mM}$ fumarate. Temperature optimum was determined using media with a $\mathrm{pH}^{25^{\circ} \mathrm{C}} 8.0$ in a temperaturegradient shaking incubator (Scientific Industries) set between 30 and $80^{\circ} \mathrm{C}$ with a $2{ }^{\circ} \mathrm{C}$ interval. Increase in cell numbers was followed for up to 2 weeks. The $\mathrm{pH}$ range for growth was determined at $52^{\circ} \mathrm{C}$ using the mineral media with $0.05 \%(\mathrm{v} / \mathrm{w})$ yeast extract and supplemented with a mixture of $10 \mathrm{mM}$ each of MES, HEPES, CAPS and TAPS as buffers for the different $\mathrm{pH}$ values. The $\mathrm{pH}^{25^{\circ} \mathrm{C}}$ values were adjusted by titration with $\mathrm{HCl}(5 \mathrm{M})$ and $\mathrm{NaOH}(5 \mathrm{M})$ before autoclaving and measured at room temperature again after $30 \mathrm{~min}$ of incubation. Salt requirement and tolerance was determined at $\mathrm{pH}^{25^{\circ} \mathrm{C}} 8.2$ and $55^{\circ} \mathrm{C}$ over a range from 0 to $15 \% \mathrm{NaCl}(\mathrm{w} / \mathrm{v})$ by measuring increase of optical density $(600 \mathrm{~nm})$ over time and calculating the doubling time of each individual culture.

\section{Microscopy}

Light microscopy: Routine examinations and cell counts were performed with an Olympus microscope (VANOX). Phase-contrast micrographs of bacteria were taken using agar-coated slides.

Scanning electron microscopy (SEM): Cells were fixed in $2 \%$ glutaraldehyde $/ 0.1 \mathrm{M}$ cacodylate, post-fixed in osmium tetroxide $/ 0.1 \mathrm{M}$ cacodylate, dehydrated through graded ethanol washes, critical point dried and coated with gold by an SPI-Module Sputter Coater. SEM images were gathered on LEO 982 SEM/FEG using an accelerating voltage of $5 \mathrm{kV}$.

Transmission electron microscopy (TEM): Cultured cells were fixed in $2 \%$ glutaraldehyde $/ 0.1 \mathrm{M}$ cacodylate buffer for $1 \mathrm{~h}(\mathrm{RT})$, rinsed, and post-fixed in $1 \%$ osmium tetroxide $\left(\mathrm{OsO}_{4}\right)$ for $1 \mathrm{~h}\left(4^{\circ} \mathrm{C}\right)$. Samples were then washed in deionized water, dehydrated stepwise with increased percentage of ethanol washes and embedded in Epon 812 resin. Cells were infiltrated in fresh resin and polymerized for $24-48 \mathrm{~h}$ at $60^{\circ} \mathrm{C}$. Thick sections of $50 \mathrm{~nm}$ thickness were cut using a diamond knife and post-stained with $4 \%$ uranyl acetate for $30 \mathrm{~min}$ followed by staining in $1 \%$ lead citrate for $5 \mathrm{~min}$. TEM images were captured on a JEOL $100 \mathrm{CX}$ with an accelerating voltage of $80 \mathrm{kV}$.
Lipid analysis

Bacterial cell membrane lipids were extracted from lyophilized cells grown in $0.8 \% \mathrm{w} / \mathrm{v}$ nutrient broth (Difco) under optimal conditions $(\mathrm{pH} \mathrm{8.3,} \mathrm{temperature}$ $52^{\circ} \mathrm{C}$ ) and collected at the late exponential growth phase by centrifugation. Cells were kept under oxygen-free $\mathrm{N}_{2}$ gas at $-80^{\circ} \mathrm{C}$ until analysis. The total lipids were extracted, fractionated and transformed to obtain fatty acid methyl esters (FAME) of phospholipids as described previously (Guckert et al. 1985). FAMEs were analyzed by gas chromatography equipped with a flame ionization detector (Hewlett-Packard 6890) (Guckert et al. 1985). The commercial bacterial acid methyl ester (BAME) standard and GC-MS system were used for peak identification.

\section{Biochemical characterization}

Sensitivity to antibiotics was determined using Sensititre COMEQ2F plates (Trek Diagnostic Systems Ltd., UK). Biochemical characterization was performed following Claus and Berkeley (1986) API 20E strips (BioMerieux Inc.) and the BBL Crystal GP ID system (Becton Dickinson and Company, USA). Incubation temperature was $50^{\circ} \mathrm{C}$.

DNA isolation and base composition

DNA was extracted using Qiagen DNeasy Tissue kit (Qiagen Inc.) according to the manufacture's instruction. The DNA $\mathrm{G}+\mathrm{C}$ content was determined by high-performance liquid chromatography as described previously (Mesbah et al. 1989).

\section{S rRNA gene sequence}

16S rRNA genes were amplified using the universal primer pairs 27f and 1492r (Escherichia coli numbering). PCR was conducted with 30 cycles of amplification at $94^{\circ} \mathrm{C}(1 \mathrm{~min}), 58^{\circ} \mathrm{C}(30 \mathrm{~s})$ and $72^{\circ} \mathrm{C}(30 \mathrm{~s})$, and a final elongation step of $72^{\circ} \mathrm{C}$ for $7 \mathrm{~min}$. PCR products were purified using Qiaquick PCR purification Kit (Qiagen Inc.), and sequenced by Macrogen Inc. (Seoul, Korea). The assembled 16S rRNA gene sequence was aligned with a representative set of $16 \mathrm{~S}$ rRNA sequences obtained from the GenBank database using ClustalX software (Higgins and Sharp 1988). Pairwise evolutionary distances were calculated by using the correction of Jukes and Cantor (1969). Phylogenetic trees were constructed with both neighbor-joining (Saitou and Nei 1987) and maximumparsimony methods, with bootstrap analysis of 1,000 replications using the Mega 3.1 software (Kumar et al. 2004). 
PCR amplification of $\operatorname{cox} \mathrm{L}$ gene fragments

PCR amplification of fragments of $\operatorname{cox} \mathrm{L}$, which codes for the large subunit of $\mathrm{CO}$ dehydrogenase, was carried out using $50 \mu \mathrm{l}$ reaction in $200 \mu \mathrm{l}$ tubes. Reactions contained standard final concentrations of deoxynucleoside triphosphates and buffer and 0.5U of MasterTaq DNA Polymerase (Brinkmann Inc.); primers were present at $0.1 \mu \mathrm{M}$ each and magnesium ion was present at $1.5 \mathrm{mM}$. The final DNA template concentration in the reaction was 3-4 ng. Two seperate reactions were carried out using primer sets that target authentic (OMP) and putative (BMS) cox $\mathrm{L}$ fragments. The forward primers for OMP and BMS fragments have the following nucleic acid sequences: OMPf (5'-GGCGGCTT[C/T]GG[C/ G]AA[C/G] AAGGT-3') and BMSf (5'- GGCGGCT $\left.\mathrm{T}[\mathrm{C} / \mathrm{T}] \mathrm{GG}[\mathrm{C} / \mathrm{G}] \mathrm{TC}[\mathrm{C} / \mathrm{G}] \mathrm{AAGAT}-3^{\prime}\right)$. The same reverse primer was used in both reactions: $\mathrm{O} / \mathrm{Br} \quad\left(5^{\prime}-[\mathrm{C} /\right.$ T]TCGA[T/C]GATCATCGG[A/G]TTGA-3'). A DNA extract from Stappia aggregata (King 2003), a known CO-oxidizer was used for a positive control in both reactions. Amplification was completed using an Eppendorf Mastercycler thermocycler (Brinkmann Inc.). First, the templates were denatured for $3 \mathrm{~min}$ at $94^{\circ} \mathrm{C}$, then 30 cycles of the following steps were completed: denaturation for $45 \mathrm{~s}$ at $94^{\circ} \mathrm{C}$, annealing for $60 \mathrm{~s}$ at $58^{\circ} \mathrm{C}$ and extension for $90 \mathrm{~s}$ at $72^{\circ} \mathrm{C}$. The 30 cycles were followed by a final $10 \mathrm{~min}$ extension at $72^{\circ} \mathrm{C}$. PCR products were viewed under UV light after standard ethidium bromide gel electrophoresis.

\section{Results}

Colony and cell morphology

Four to ten-day-old colonies of strain JW/WZ-YB58 ${ }^{\mathrm{T}}$, growing aerobically on solidified (agar, $2 \% \mathrm{w} / \mathrm{v}$ ) mineral media containing $0.05 \%(\mathrm{w} / \mathrm{v})$ yeast extract, were circular with entire edges, $2-3 \mathrm{~mm}$ in diameter and transparent. After an additional week, swarming was observed leading to irregular spreading of the colonies. Cells of strain $\mathrm{JW} / \mathrm{WZ}-\mathrm{YB} 58^{\mathrm{T}}$ were motile rods of $0.7-$ $0.8 \mu \mathrm{m}$ in width and 5.5-12 $\mu \mathrm{m}$ in length with rounded ends (Fig. 1) and two to five peritrichously inserted flagella (Fig. 2a). Cells from early stationary phase tended to form chains of 3-12 cells. Spherical spores (1.2$1.6 \mu \mathrm{m}$ in diameter) were located terminally with swelling (around $2 \mu \mathrm{m}$ in diameter) of the mother cell (drumstick morphology) (Fig. 1). TEM revealed that the cells contain two types of unusual cytoplasmic inclusions of unknown nature and function and thus need further studies in the future.

\section{Physiology}

Strain JW/WZ-YB58 ${ }^{\mathrm{T}}$ was unable to use CO $(1-5 \% \mathrm{v} / \mathrm{v})$ or $\mathrm{CO}_{2}(10 \% \mathrm{v} / \mathrm{v})$ as the sole carbon source in the

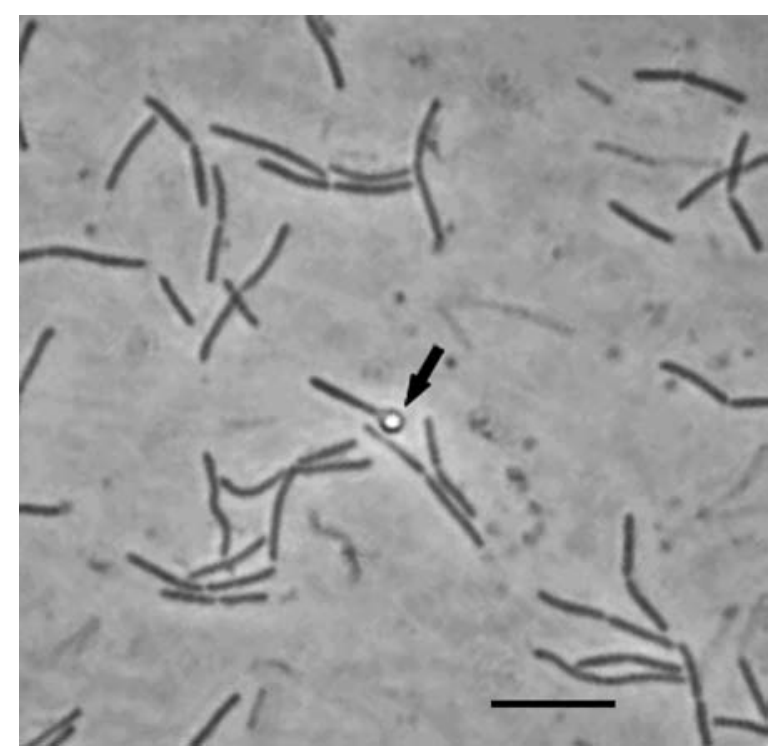

Fig. 1 Phase-contrast microphotograph of strain JW/WZ-YB58 ${ }^{\mathrm{T}}$. Cells from the late exponential growth phase. Arrows indicate sporulated cell. Bar represents $10 \mu \mathrm{m}$

presence or absence of 10-20\% (v/v) $\mathrm{H}_{2}$ within a 4-week incubation with or without shaking. No CO-oxidation was observed at $100 \mathrm{ppm} \mathrm{CO}$, neither, by using a PCR assay, could a presence of either the authentic or the putative cox $\mathrm{L}$ fragments of a gene for CoxL be demonstrated, suggesting that the bacterium does not contain the ability of CO-utilization. However, while growing on $0.05 \%(\mathrm{w} / \mathrm{v})$ yeast extract alone or with 10 $\mathrm{mM}$ pyruvate, the cultures were not inhibited by the presence of air containing $0-70 \%(\mathrm{v} / \mathrm{v}) \mathrm{CO}$ and still grew under $90 \%(\mathrm{v} / \mathrm{v})$ CO-containing air but the cell morphology became irregular. In the presence of $0.02 \%(\mathrm{w} /$ v) yeast extract, strain $\mathrm{JW} / \mathrm{WZ}-\mathrm{YB}^{\mathrm{B}} 8^{\mathrm{T}}$ grew on complex organic compounds as carbon and energy sources, such as beef extract, casamino acid, peptone, starch and tryptone. The following compounds served as carbon and energy source: dextrin, raffinose, lactose, sucrose, arabinose, fructose, D-galactose, D-glucose, D-mannose, trehalose, gluconate, glutamate, fumarate, lactate, pyruvate and acetate. Cells did not grow on alcohols and sugar alcohols. Cells were strict aerobes and unable to use nitrate, nitrite, fumarate, thiosulfate, $\mathrm{Fe}(\mathrm{III})$ hydroxide and $\mathrm{Fe}(\mathrm{III})$ citrate as electron acceptors for anaerobic growth while using $20-\mathrm{mM}$ pyruvate as the carbon source. The substrate and electron acceptor spectrum of strain JW/WZ-YB $58^{\mathrm{T}}$ indicated an aerobic, organoheterotrophic and CO-tolerant physiology.

The temperature range for growth was between 42 and $64^{\circ} \mathrm{C}$, with an optimum at $50-52^{\circ} \mathrm{C}$ at $\mathrm{pH}^{25^{\circ} \mathrm{C}} 8.0$. No growth occurred at $40^{\circ} \mathrm{C}$ or $66^{\circ} \mathrm{C}$. At $52^{\circ} \mathrm{C}$, the strain grew at $\mathrm{pH}^{25^{\circ} \mathrm{C}}$ between 6.4 and 9.7 , with an optimum of 8.2 to 8.4 . No growth was observed at or below $\mathrm{pH}^{25^{\circ} \mathrm{C}}$ 6.1 and at or above $\mathrm{pH}^{25^{\circ} \mathrm{C}} 10.0$. However, the growth of the strain at or below $\mathrm{pH}^{25^{\circ} \mathrm{C}} 7$ was very poor with doubling times longer than $14 \mathrm{~h}$. The observed minimal 
Fig. 2 Electron micrographs. (a) SEM revealed retarded perictrichous flagellation (arrowhead) and an uneven cell surface. Scale bar $=4 \mu \mathrm{m}$.

(b) TEM revealed organized internal features (white arrow) and several circular electron dense bodies (black arrow) of unknown function and nature in each cell. Scale bar $=1 \mu \mathrm{m}$ (courtesy of Rich Davis, UGA)
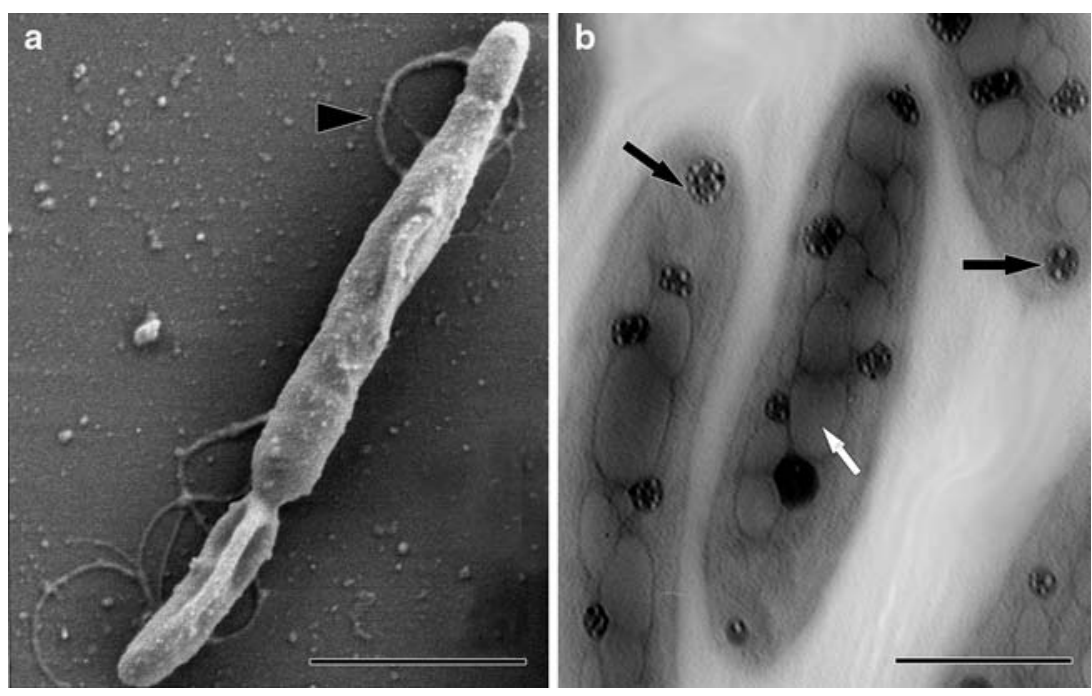

doubling time under optimal growth conditions $\left(\mathrm{pH}^{25 \mathrm{C}}\right.$ $8.3,52^{\circ} \mathrm{C}$ ) was $2 \mathrm{~h}$.

\section{Biochemical characterization}

Cultures were positive for Gram-staining reaction, oxidase reactions, ONPG hydrolysis and gelatin hydrolysis. Results were negative for catalase reaction, VogesProskauer reaction, indole production, urea hydrolysis and starch hydrolysis.

Cellular polar lipids of strain $\mathrm{JW} / \mathrm{WZ}-\mathrm{YB} 58^{\mathrm{T}}$ were dominated by branched saturated fatty acids including iso-14:0 (1\%), iso-15:0 (24.5\%), anteiso-15:0 (18.3\%), iso-16:0 (9.9\%), iso-17:0 (17.5\%) and anteiso-17:0 $(9.7 \%)$ accounting for about $81 \%$ of the total fatty acids (area \%). Other important fatty acids were 14:0 (1.2\%), 15:0 (5.1\%), 16:1 (2.1\%), 16:0 (7.6\%), 17:0 (1.1\%), 18:1 $(0.9 \%)$ and an unknown fatty acid $(1.1 \%)$.

The strain JW/WZ-YB58 ${ }^{\mathrm{T}}$ was sensitive to the following antibiotics $\left(\mu \mathrm{g} \mathrm{ml}^{-1}\right)$ : Amikacin, 4; Amoxicillin/ clavulanic acid, 4/2; Ampicillin, 0.25; Cefazolin, 0.25; Cefoxitin, 2; Cefpodoxime, 2; Ceftiofur, 0.25; Cephalothin, 2; Chloramphenicol, 4; Clindamycin, 0.25; Enrofloxacin, 0.5; Erythromycin, 0.5; Imipenem, 1; Gentamicin, 1; Marbofloxacin, 0.25; Orbifloxacin, 1; Oxacillin,2; Penicillin, 0.06; Rifampin, 1; Tetracycline, 1; Ticarcillin, 8; Ticarcillin/clavulanic acid, 8/2; Trimethoprim/sulphamethoxazole, 0.5/9.5.

\section{DNA composition and 16S rDNA sequences}

The $\mathrm{G}+\mathrm{C}$ content of genomic DNA of strain JW/WZ$\mathrm{YB}^{\mathrm{T}}{ }^{\mathrm{T}}$ was $45 \mathrm{~mol} \%$ (chromatographic method). The obtained 16S rRNA sequence (Genbank accession number DQ221694) contained 1,436 nucleotides corresponding to positions $33-1,470$ of the E. coli $16 \mathrm{~S}$ rRNA gene sequence. Using BLAST to compare with the currently available sequences in GenBank, no closely related sequence was found. The sequence suggest a distant relationship to the alkaliphilic isolate Bacillus $\mathrm{sp}$. TA2.A1 (AF113512) (96.6\% similarity) (Cook et al. 2003; Olsson et al. 2003; Peddie et al. 2000). A phylogenetic tree, based on neighbor-joining method, revealed that strain JW/WZ-YB $58^{\mathrm{T}}$ was phylogenetically related to the members of Bacillaceae. The closest neighbor was Bacillus horti DSM 12751 (93.1\% similarity), a mesophilic and alkaliphilic bacterium isolated from the soil in Japan (Fig. 3). Similarities to other previously described Bacillaceae members were low (around 90.0\%), and nearly equally distant to other major groups; for example, B. clarkii DSM $8720^{\mathrm{T}} 91.0 \%$ (X76444), B. halodurans DSM497 ${ }^{\mathrm{T}}$ 90.3\% (AJ302709), B. subtilis W168/PY79 89.4\% (K00637), Geobacillus subterraneus DSM13552 ${ }^{\mathrm{T}}$ 90.6\% (AF276306), G. stearothermophilus DSM6285 ${ }^{\mathrm{T}}$ 90.3\% (AY608989), Aneurinibacillus thermoaerophilus DSM10154 90\% (X94186), Brevibacillus thermoruber DSM7064 ${ }^{\mathrm{T}} 89.2 \%$ (Z16921), and B. thermocloacae DSM5250 $89.6 \%$ (Z26939).

\section{Discussion}

The $\mathrm{pH}$ and temperature profiles indicate that the strain $\mathrm{JW} / \mathrm{WZ}-\mathrm{YB} 8^{\mathrm{T}}{ }^{\mathrm{i}}$ is a facultative alkaliphilic, moderately thermophilic Gram staining and Gram-type positive (Wiegel 1981) rod-shaped bacterium, which differs from the closest phylogenetic neighbor $B$. horti in many aspects. Among the most distinguishable characteristics are the range of growth temperature and $\mathrm{NaCl}$ tolerance, spore morphology, $\mathrm{O}_{2}$ requirement, Gram-staining and catalase reactions (Table 1). The 16S rRNA gene sequence analysis reveals that the other phylogenetic neighbors are mainly alkaliphilic or thermophilic members of the Bacillaceae family. However, the growth of strain $\mathrm{JW} / \mathrm{WZ}-\mathrm{YB} 58^{\mathrm{T}}$ occurs at higher temperatures and lower $\mathrm{pH}$ than other strictly alkaliphilic Bacillus species. In addition, strain $\mathrm{JW} / \mathrm{WZ}-\mathrm{YB} 58^{\mathrm{T}}$ is lower in tolerance to salt $(0-6 \%, \mathrm{w} / \mathrm{v}, \mathrm{NaCl})$ and higher in DNA $\mathrm{G}+\mathrm{C}$ content than major alkaliphilic Bacillus species (Nielsen 
Fig. 3 Phylogenetic tree based on $16 \mathrm{~S}$ rRNA gene sequence. Comparison between strain $\mathrm{JW} / \mathrm{WZ}-\mathrm{YB}^{\mathrm{T}} 8^{\mathrm{T}}$ and other related, mainly alkaliphilic and thermophilic species was based on neighbor-joining method with bootstrap analysis of 1,000 replicates. Bootstrap values greater than $50 \%$ are shown. $B a r$ equals $0.02 K_{\text {nuc }}$

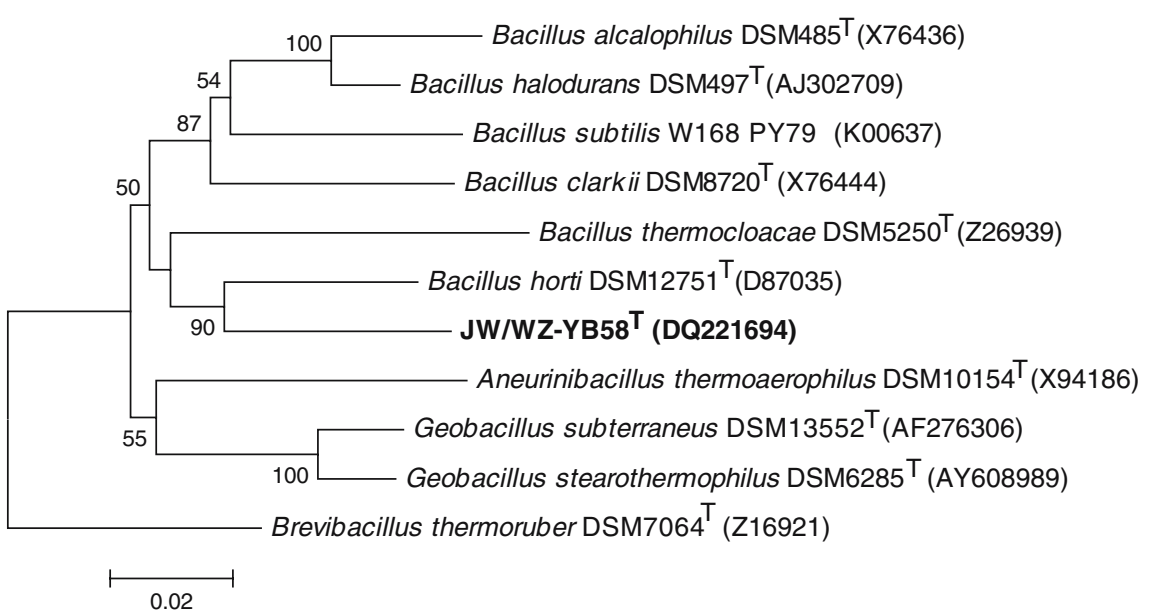

Table 1 Differentiating characteristics of strain JW/WZ-YB58 ${ }^{\mathrm{T}}$ and other related Firmicutes species

\begin{tabular}{|c|c|c|c|c|c|c|c|c|c|c|}
\hline Characteristics & 1 & 2 & 3 & 4 & 5 & 6 & 7 & 8 & 9 & 10 \\
\hline \multicolumn{11}{|l|}{ Sporangia } \\
\hline Shape & $\mathrm{S}$ & $\mathrm{E}$ & ND & $\mathrm{E}$ & $\mathrm{E}$ & E & $\mathrm{E}$ & $\mathrm{E}$ & $\mathrm{E}$ & $\mathrm{E}$ \\
\hline Position & $\mathrm{T}$ & $\mathrm{S}$ & ND & $\mathrm{S}$ & $\mathrm{S}$ & ST & ST & $\mathrm{T}$ & $\mathrm{C}$ & ST \\
\hline Sporangia swollen & + & ND & ND & - & + & E & - & $\mathrm{v}$ & + & + \\
\hline Catalase & - & + & ND & + & ND & + & + & + & - & - \\
\hline Growth at $\mathrm{pH} 7$ & + & + & - & - & $\mathrm{v}$ & - & + & + & + & + \\
\hline \multicolumn{11}{|l|}{ Growth at } \\
\hline $10^{\circ} \mathrm{C}$ & - & - & - & + & - & - & - & - & - & - \\
\hline $40^{\circ} \mathrm{C}$ & - & + & + & + & + & + & - & + & + & + \\
\hline $50^{\circ} \mathrm{C}$ & + & - & - & - & + & + & + & + & + & + \\
\hline Growth in $10 \%(\mathrm{w} / \mathrm{v}) \mathrm{NaCl}$ & - & + & + & - & $\mathrm{v}$ & - & - & - & - & - \\
\hline Hydrolysis of starch & - & + & - & + & + & - & + & + & - & + \\
\hline Reduction of nitrate & - & + & + & - & - & - & + & - & - & - \\
\hline $\mathrm{Mol} \% \mathrm{G}+\mathrm{C}$ content & 45 & $40.2-40.9$ & $42.4-43.0$ & $36.2-38.4$ & $42.1-43.9$ & $41.7-42.1$ & $49.7-52.3$ & 51.9 & 46.7 & $56.2-57.8$ \\
\hline
\end{tabular}

Abbreviations: +, positive; -, negative; $v$ variable; $N D$ not determined; $S$ spherical; $E$ ellipsoidal; $T$ terminal; $S$ subterminal; $C$ central. Species: 1, JW/WZ-YB58 ; 2, B. horti (Yumoto et al. 1998); 3, B. clarkii; 4, B. alcolophilus; 5, B. halodurans (Nielsen et al. 1995); 6, B. thermocloacae (Demharter and Hensel 1989); 7, Gb. subterraneus (Nazina et al. 2001); 8, Gb. stearothermophilus (Kampfer 1994); 9, Anb. thermoaerophilus (Meier-Stauffer et al. 1996); 10, Bb. thermoruber (Manachini et al. 1985)

et al. 1995) (Table 1). Thermophilic members of the order Bacillales such as species belonging to the genera Geobacillus, Aneurinibacillus and Brevibacillus, on the other hand, usually grow optimally at neutral or slightly acidic $\mathrm{pH}$ (Nazina et al. 2001). The absence of a positive catalase reaction in strain $\mathrm{JW} / \mathrm{WZ}-\mathrm{YB}^{\mathrm{B}} 8^{\mathrm{T}}$ distinguishes it from the majority of Bacillus species, which commonly show positive catalase reactions (Claus and Berkeley 1986). Terminally located spherical spores produced by strain $\mathrm{JW} / \mathrm{WZ}-\mathrm{YB} 58^{\mathrm{T}}$ rarely occur in its phylogenetic neighbors, which usually form centrally or sub-terminally located ellipsoidal spores (Table 1). The DNA $\mathrm{G}+\mathrm{C}$ content for strain $\mathrm{JW} / \mathrm{WZ}-\mathrm{YB}^{\mathrm{T}} 8^{\mathrm{T}}$ is $45 \mathrm{~mol} \%$ and thus greater than that of most mesophilic-alkaliphilic Bacillus species but lower than that of neutral-thermophiles (Nazina et al. 2001; Manachini et al. 1985) (Table 1). Presently it is unclear how far the insensitivity toward $\mathrm{CO}$ is a taxonomically useful property because $\mathrm{CO}$-utilization and/or inhibition by $\mathrm{CO}$ is not a common test for characterizing novel microorganisms, especially thermophiles. Gee and Brown (1980) and Cypionka and
Meyer (1982) showed that different bacteria which includes E. coli (although at a slower growth rate), are not inhibited by concentrations of up to $30 \% \mathrm{v} / \mathrm{v}$ CO. Furthermore the question whether an organism can utilize $\mathrm{CO}$ needs to be carefully examined, since $\mathrm{CO}$ utilization can be inhibited by elevated $\mathrm{CO}$ concentrations (King 2003; King et al., unpublished data; Moran et al. 2004) which includes e.g., CO-oxidizing members of the marine genus Stappia, which do not oxidize CO above $1000 \mathrm{ppm}$ (King, unpublished data). However, the failure to demonstrate the presence of the $\operatorname{cox} \mathrm{L}$ gene, which codes for the large subunit of $\mathrm{CO}$ dehydrogenase, suggests that this bacterium is not a CO-utilizer. At this time it is not clear how important the observed COinsensitivity is for the isolate to function within the microbial mat from the hot pool Zarvarzin II and possibly in similar mats in the caldera. King and Weber (unpublished results) have measured in situ $\mathrm{CO}$ formation and $\mathrm{CO}$ utilization in these mats. The roles of $\mathrm{CO}$ utilization and CO-insensitivity of bacteria in the hot spring mats need further investigations. 
Cell membranes of Bacillus species are characterized by branched saturated fatty acids (Kaneda 1967; Claus and Berkeley 1986; Kampfer 1994; Nazina et al. 2001). The majority of alkaliphilic Bacillus species are dominated by anteiso-fatty acids with the ratio of total anteiso-/total iso- greater than 1, whereas strain $\mathrm{JW} / \mathrm{WZ}$ $\mathrm{YB}^{\mathrm{T}}{ }^{\mathrm{T}}$ has a total anteiso-/total iso- ratio of only 0.53 with the iso-15:0 as the most abundant component (Table 2). Thermophilic Geobacillus species and Aneurinibacillus species have similar cellular fatty acid compositions to strain $\mathrm{JW} / \mathrm{WZ}-\mathrm{YB} 58^{\mathrm{T}}$ with iso-15:0 being the most abundant fatty acid (Nazina et al. 2001; Heyndrickx et al. 1997; Meier-Stauffer et al. 1996). However, the total anteiso-/total iso- ratio is usually lower than 0.4 for Geobacillus species and even lower for Aneurinibacillus species (Nazina et al. 2001; MeierStauffer et al. 1996), which may be due to the lower growth $\mathrm{pH}$ of species in these genera than that of strain $\mathrm{JW} / \mathrm{WZ}-\mathrm{YB}^{\mathrm{T}}{ }^{\mathrm{T}}$.

On the basis of physiological characteristics, phenotypic and phylogenetic properties, the isolate is placed according to the recent electronic Bergey's Outline (Garrity et al. 2004) within the Phylum BXIII Firmicutes, Class Bacilli, Order I Bacillales and tentatively Family I Bacillaceae into a novel taxa, Thermalkalibacillus uzonensis gen. nov. sp. nov. with strain JW/WZ-YB58 ${ }^{\mathrm{T}}$ (ATCC BAA-1258 $=$ DSM 17740) as the type strain for the type species T. uzonensis. Besides the type genus Bacillus with $B$. subtilis as type species, the Family I Bacillaceae contains also the genus Geobacillus (see Fig. 3). The genus Geobacillus contains several thermophilic and alkali-tolerant/alkaliphilic species formerly belonging to the genus Bacillus. However, the genus
Anaeurobacillus (see Fig. 3) is assigned to Family V Paenibacillaceae (Garrison et al. 2004). Constructing several trees using the type species of the different genera and various algorithms (figures not shown), reveals that the phylogeny of the Bacillales is not clear at this time, as is evident from low (below 50\%) boot strap values. Furthermore, defining the boundary for the novel genus has to await further isolations of species and strains belonging to this group, that is, to decide whether the closest neighbor in the phylogenetic trees we constructed, B. horti (Fig. 3), belongs to the novel genus or not.

\section{Description of Thermalkalibacillus gen. nov}

Thermalkalibacillus [therm.al.ka.li.ba.cil.lus. Gr. n. thermê, heat; Arabic word alkali (al-qaliy), the ashes of saltwort; L. masc. n. bacillus, a small staff, a wand; N.L. masc. n. Thermalkalibacillus, rod, loving combined growth conditions of elevated temperature and alkaline $\mathrm{pH}]$.

Cells are aerobic, spore-forming rods; thermophilic and facultative alkaliphilic or alkali-tolerant strict heterotrophs; utilize carbohydrate and organic acids for growth; DNA $\mathrm{G}+\mathrm{C} \mathrm{mol} \%$ is about $45 \%$.

\section{Description of $\boldsymbol{T}$. uzonensis sp. nov}

T. uzonensis [u.zo.nen'sis. N.L. masc. adj. uzonensis pertaining to the isolation habitate Uzon Caldera, east of Mt Uzon in Kamchatka (Far East Russia)].

Table 2 Membrane phospholipid fatty acid composition of strain JW/WZ-YB58 ${ }^{\mathrm{T}}$ and other related species (shown in percentage of total fatty acid)

\begin{tabular}{|c|c|c|c|c|c|c|c|}
\hline Fatty acids & 1 & 2 & 3 & 4 & 5 & 6 & 7 \\
\hline $\mathrm{i}-14: 0$ & 1.0 & - & 0.6 & 1.8 & 0.1 & 2.9 & 0.2 \\
\hline $\mathrm{i}-15: 0$ & 24.5 & 38 & 32 & 29.1 & 40 & 37.8 & 54.3 \\
\hline$a-15: 0$ & 18.3 & 30 & 43 & 37.9 & 6.4 & 2.3 & 0.6 \\
\hline $15: 0$ & 5.1 & - & 0.3 & - & 0.5 & 1.4 & 0.6 \\
\hline $\mathrm{i}-16: 0$ & 9.9 & 4.4 & 1 & 4.9 & 6.2 & 29.2 & 2.3 \\
\hline $\mathrm{i}-17: 0$ & 17.5 & 1.4 & 4.3 & 11.2 & 17 & 18.5 & 32.8 \\
\hline a-17:0 & 9.7 & 7.9 & 11 & 9.6 & 13 & 5.8 & 0.8 \\
\hline i-17:1 & - & - & 1.7 & 0.3 & - & - & - \\
\hline a-17:1 & - & - & 0.9 & 0.2 & - & - & - \\
\hline C17:0 & 1.1 & 1.9 & - & - & - & 0.4 & 0.2 \\
\hline i-16:1 & - & - & - & 0.1 & - & - & - \\
\hline Total & 100 & 101 & 99 & 100 & 100 & 100 & 100 \\
\hline
\end{tabular}

1, JW/WZ-YB58 ${ }^{\mathrm{T}} ; 2$, B. horti DSM12751 ${ }^{\mathrm{T}}$ (Yumoto et al. 1998); 3, B. alcalophilus DSM485 ${ }^{\mathrm{T}}$; 4, B. subtilus (Yumoto et al. 2003); 5, G. stearothermophilus DSM6285 ${ }^{\mathrm{T}}$ (Kampfer 1994); 6, G.subterraneus DSM13552 ${ }^{\mathrm{T}}$ (Nazina et al. 2001); 7, Aneurinibacillus thermoaerophilus DSM10154 ${ }^{\mathrm{T}}$ (Meier-Stauffer et al. 1996) 
Cells are Gram-type (Wiegel 1981) and Gram-staining positive, straight to slightly curved rods with $0.7-$ $0.8 \mu \mathrm{m} \times 5.5-12 \mu \mathrm{m}$ in dimension. Terminally located spherical spores (1.2-1.6 $\mu \mathrm{m}$ in diameter) cause swelling of the mother cells. Cells are motile with $2-5$ peritrichous flagella. Growth only under aerobic conditions observed. Colonies on nutrient broth agar are circular with entire edges and transparent. Swarming occurs when colony ages. Oxidase reactions, ONPG hydrolysis and gelatin hydrolysis are positive. Catalase reaction, Voges-Proskauer reaction, indole production, urea hydrolysis and starch hydrolysis are negative. At $\mathrm{pH}^{25^{\circ} \mathrm{C}}$ 8.0 , the temperature range is $42-64^{\circ} \mathrm{C}$ with optimum at $50-52^{\circ} \mathrm{C}$. The $\mathrm{pH}^{25^{\circ} \mathrm{C}}$ range is $6.4-9.7$ (pH optimum $8.2-$ 8.4) when grown at $52^{\circ} \mathrm{C}$. Tolerated $\mathrm{NaCl}$ concentration range is $0-6 \%(\mathrm{w} / \mathrm{v})$. Cells grow on complex substrates (such as yeast extract), carbohydrates and acids but not on alcohols and sugar alcohols. Acid production occurs from trehalose, lactose, sucrose, arabinose and fructose. Major cellular fatty acids are iso-15:0 (24.5\%), anteiso15:0 (18.3\%), iso-16:0 (9.9\%), iso-17:0 (17.5\%), anteiso17:0 $(9.7 \%)$ and $16: 0(7.6 \%)$. The $\mathrm{G}+\mathrm{C}$ content of genomic DNA is $45 \mathrm{~mol} \%$ (chromatographic method). Cells do not grow chemolithoautotrophically on $1-5 \%$ $\mathrm{v} / \mathrm{v} \mathrm{CO}$ or $10 \% \mathrm{CO}_{2}$ with or without $\mathrm{H}_{2}$ and do not oxidize $\mathrm{CO}$ at low concentrations $(100 \mathrm{ppm})$. Grown under shaking, $\mathrm{CO}$ is tolerated up to $90 \%(\mathrm{v} / \mathrm{v})$ in aircontaining gas headspace. The type strain is JW/WZ$\mathrm{YB}^{\mathrm{T}}{ }^{\mathrm{T}}$ (ATCC BAA-1258; DSM 17740), which was isolated from a microbial mat sample collected from the edges of the hot spring Zarvarzin II in the Uzon Caldera, Kamchatka (Far East Russia). The GenBank accession number for the 16S rRNA gene sequence of the type strain is DQ221694.

Acknowledgements We thank Rich Davis for performing the electron microscopy, Jean P. Euzeby for help with the correct naming of T. uzonensis. We are indebted to Elizaveta Bonch-Osmolovskaya (RAS-Moscow) and Gennadii Karpov (Petropavlovsk-kamchatkii) for logistic help for our field season and obtaining sampling permits. This research was supported by a grant through National Science Foundation Microbial Observatory Program NSF-MCB 0238407 (JW, CSR) and partially supported by the Environmental Remediation Sciences Division of the Office of Biologic and Environmental Research, US Department of Energy through the Financial Assistant Award to the University of Georgia Research Foundation (CLZ, CSR).

\section{References}

Blum JS, Bindi AB, Buzzelli J, Stolz JF, Oremland RS (1998) Bacillus arsenicoselenatis, sp. nov., and Bacillus selenitireducens, sp. nov: two haloalkaliphiles from Mono lake, California that respire oxyanions of selenium and arsenic. Arch Microbiol 171:19-30

Claus D, Berkeley RCW (1986) Genus Bacillus cohn 1872. In: Sneath PHA, Mair NS, Sharpe ME, Holt JG (eds) Bergey's Manual of Systematic Bacteriology. Williams \& Winkins, Baltimore, pp 1105-1139

Conrad R (1996) Soil microorganisms as controllers of atmospheric trace gases $\left(\mathrm{H}_{2}, \mathrm{CO}, \mathrm{CH}_{4}, \mathrm{OCS}, \mathrm{N}_{2} \mathrm{O}\right.$ and $\left.\mathrm{NO}\right)$. Microbiol Rev 60:609-640
Cook GM, Keis S, Morgan HW, van Ballmoos C, Matthey U, Kaim G, Dimroth P (2003) Purification and biochemical characterization of the F1FO-ATP synthase from thermoalkaliphilic Bacillus sp. strain TA2.A1. J Bacteriol 185:4442-4449

Cypionka H, Meyer O (1982) Influence of carbon monoxide on growth and respiration of carboxydotrophic and other aerobic organisms. FEMS Microbiol Lett 15:209-214

Demharter W, Hensel R (1989) Bacillus thermocloaceae sp. nov, a new thermophilic species from sewage-sludge. Syst Appl Microbiol. 11:272-276

Dunfield KE, King GM (2004) Molecular analysis of carbon monoxide-oxidizing bacteria colonizing recent Hawaiian volcanic deposits. Appl Environ Microbiol 70:4242-4248

Garrity MG, Bell JA, Lilburn TG (2004) Taxonomic Outline of the Prokaryotes. Bergey's Manual of Systematic Bacteriology, second edition, release 5.0 May 2004. http://141.150.157.80/ bergeysoutline/outline/bergeysoutline_5_2004.pdf

Gee DL, Brown WD (1980) The effect of carbon monoxide on bacterial growth. Meat Science 5:215-222

Guckert JB, Antworth CP, Nichols PD, White DC (1985) Phospholipid, ester-linked fatty-acid profiles as reproducible assays for changes in prokaryotic community structure of estuarine sediments. FEMS Microbiol Ecol 31:147-158

Hardy K, King GM (2001) Enrichment of a high affinity CO-oxidizer in Maine forest soil. Appl Environ Microbiol 67:36713676

Heyndrickx M, Lebbe L, Vancanneyt M, Kersters K, de Vos P, Logan NA, Forsyth G, Nazli S, Ali N, Berkeley RCW (1997) A polyphasic reassessment of the genus Aneurinibacillus, reclassification of Bacillus thermoaerophilus (Meier-stauffer et al 1996) as Aneurinibacillus thermoaerophilus comb. nov., and emended descriptions of $A$. aneurinilvticus corrig, A. migulanus, and $A$. thermoaerophilus. Int J Syst Bacteriol 47:808-817

Higgins DG, Sharp PM (1988) Clustal: a package for performing multiple sequence alignments on a microcomputer. Gene 73:237-244

Horikoshi K (1999) Alkaliphiles: Some applications of their products for biotechnology. Microbiol. Mol Biol Rev 63:735750

Horikoshi K (2004) Alkaliphiles. Proc Jpn Acad Ser B-Phys Biol Sci 80:166-178

Jukes TH, Cantor CR (1969) Evolution of protein molecules. In: Munro HN (ed) Mammalian protein metabolism. Academic, New York, pp 21-123

Kampfer P (1994) Limits and possibilities of total fatty-acid analysis for classification and identification of bacillus species. Syst Appl Microbiol 17:86-98

Kaneda T (1967) Fatty acids in genus Bacillus. I. iso- and anteisofatty acids as characteristic constituents of lipids in 10 species. J Bacteriol 93:894-903

Kevbrin VV, Romanek CS, Wiegel J (2004) Alkalithermophiles: a double challenge from extreme environments. In: Seckbach $\mathbf{J}$ (ed) Cellular origins: life in extreme habitats and astrobiology. Kluwer Academic, Dordrecht, The Netherlands

King GA (2003) Molecular and culture-based analyses of aerobic carbon monoxide oxidizer diversity. Appl Environ Microbiol 69:7257-7265

Kruger B, Meyer O (1984) Thermophilic Bacilli growing with carbon-monoxide. Arch Microbiol 139:402-408

Kumar S, Tamura K, Nei M (2004) MEGA3: integrated software for molecular evolutionary genetics analysis and sequence alignment. Briefings Bioinform 5:150-163

Manachini PL, Fortina MG, Parini C, Craveri R (1985) Bacillus thermoruber sp. nov., nom. rev., a red-pigmented thermophilic bacterium. Int J Syst Bacteriol 35:493-496

Meier-Stauffer K, et al. (1996) Description of Bacillus thermoaerophilus sp. nov., to include sugar beet isolates and Bacillus brevis ATCC 12990. Int J Syst Bacteriol 46:532-541

Mesbah M, Premachandran U, Whitman W (1989) Precise measurement of the $\mathrm{G}+\mathrm{C}$ content of deoxyribonucleic acid by high-performance liquid chromatography. Int J Syst Bacteriol 39:159-167 
Meyer O, Frunzke K, Gadkari D, Jacobitz S, Hugendieck I, Kraut M (1990) Utilization of carbon-monoxide by aerobes - recent advances. Fems Microbiol Rev 87:253-260

Moran MA, Buchan A, Gonzalez JM, Heidelberg JF, Whitman WB, Kiene RP, Henriksen JR, King GM, Belas R, Fuqua C, Brinkac L, Lewis M, Johri S, Weaver B, Pai G, Eisen JA, Rahe E, Sheldon WM, Ye W, Miller TR, Carlton J, Rasko DA, Paulsen IT, Ren Q, Daugherty SC, Deboy RT, Dodson RJ, Durkin AS, Madupu R, Nelson WC, Sullivan SA, Rosovitz MJ, Haft DH, Selengut J, Ward N (2004) Genome sequence of Silicibacter pomeroyi reveals adaptations to the marine environment. Nature 432:910-913

Nazina TN, et al. (2001) Taxonomic study of aerobic thermophilic Bacilli: descriptions of Geobacillus subterraneus gen. nov., sp. nov. and Geobacillus uzenensis sp. nov. from petroleum reservoirs and transfer of Bacillus stearothermophilus Bacillus thermocatenulatus, Bacillus thermoleovorans, Bacillus kaustophilus, Bacillus thermoglucosidasius and bacillus thermodenitrificans to Geobacillus as the new combinations $G$. stearothermophilus, G. thermocatenulatus, G. thermoleovorans, G. kaustophilus, G. thermoglucosidasius and G. thermodenitrificans. Int J Syst Evol Microbiol 51:433-446

Nielsen P, Fritze D, Priest FG (1995) Phenetic diversity of alkaliphilic Bacillus strains - proposal for 9 new species. Microbiol UK 141:1745-1761
Olsson K, Keis S, Morgan HW, Dimroth P, Cook GM (2003) Bioenergetic properties of the thermoalkaliphilic Bacillus sp. strain TA2.A1. J Bacteriol 185:461-465

Peddie CJ, Cook GM, Morgan HW (2000) Sucrose transport by the alkaliphilic, thermophilic Bacillus sp. strain TA2.A1 is dependent on a sodium gradient. Extremophiles 4:291-296

Saitou N, Nei M (1987) The neighbor-joining method: a new method for reconstructing phylogenetic trees. Mol Biol Evol 4:406-425

Widdel F, Bak F (1992) Gram-negative mesophilic sulfate-reducing bacteria. In: Balows A, Trüper HG, Dworkin M, Harder W, Schleifer H (eds) The Prokaryotes, 2nd edn. Springer-Verlag, Berlin Heidelberg New York, pp 3352-3378

Wiegel J (1981) Distinction between the Gram reaction and the Gram type of bacteria. Int J Syst Bacteriol 31:88

Yumoto I, Yamazaki K, Sawabe T, Nakano K, Kawasaki K, Ezura Y, Shinano H (1998) Bacillus horti sp. nov., a new Gram-negative alkaliphilic Bacillus. Int $\mathbf{J}$ Syst Bacteriol 48:565-571

Yumoto I, Yamaga S, Sogabe Y, Nodasaka Y, Matsuyama H, Nakajima K, Suemori A (2003) Bacillus krulwichiae sp. nov., a halotolerant obligate alkaliphile that utilizes benzoate and $\mathrm{m}$ hydroxybenzoate. Int J Syst Evol Microbiol 53:1531-1536 